The journal for July 7 , 1875 , gives an artificial table for distinguishing the downs of ten species of ducks, and that is the kind of minute detail more of which we would gladly have welcomed. It is also to the point to be told of the curious antics of the Arctic (Richardson's) skuas :-

"The birds often alighted within fifteen yards of me, raised the wings over the back-when they did this the white or dusky quills showed like a patch upon the raised wings---shammed lameness and sickness, and stood reeling from side to side as if mortally wounded. If I followed them, they continued to try and lead me off; but if I again approached the nest, they flew boldly towards me, and stooped repeatedly."

There are some vivid pictures of the tundra and its birds, there is an interesting account of the Samoyèdes, and there are some instructive notes on the habits both of birds and men, for all of which one is grateful, wishing only that there had been more of this wheat and less of the journalistic chaff.

\section{PRACTICAL SEA-FISHING.}

Practical Sea-Fishing. A Handbook for Sea Anglers. By P. L. Haslope. Pp. 274; illustrated. (London: Upcott Gill, 1905.) Price 3s. $6 d$.

$S^{E A}$ fishing is not a new form of sport, nor is it $S$ a subject which has been neglected by authors. We have several excellent works on it, such as "Sea Fishing" by "John Bickerdyke" in the Badminton Library series, and "Sea Fishing on the English Coasts" by Aflalo, so that a new book requires some justification for its production.

The work under review is perhaps worthy of a place in the sea fisherman's library, but it is, in our opinion, in no way fitter to occupy that position than either of the books already mentioned. It is obviously written by a practical sea-fisherman who has tested most, if not all, of the methods of rod and line fishing which he recommends; but it is as obviously written by a man whose experience has been mostly confined to the south coast, as south coast methods are much more often referred to than those of other parts of the country.

The author does not, however, appear to be so conversant with some of the methods of net-fishing which he discusses as he is with those of rod and line fishing. For instance, he considers the otter-trawl "a much more manageable net" for the amateur than the beam-trawl, a point we think open to doubt. It is true that the otter-trawl is more easily stowed away on board, but we think that its advantage over the beam-trawl for the amateur ends there, especially if the vessel is not a steamer. The difficulty of getting the otter-trawl to spread out and of getting it to fish properly is only known to those who have tried, and we should certainly recommend the amateur to use a beam-trawl, which, it is true, may capsize when being lowered, but otherwise will always fish when down.

When Mr. Haslope touches upon natural history or the habits of sea-fish he is clearly not so much at home as when he is discussing methods of capture. No. $188 \mathrm{I}$, vol. 73 ]
For instance, he refers to the angel fish, Rhina squatina, as a species of ray. He mixes up Atherina presbyter, the sand-smelt, and Osmerus eperlanus, the true smelt, and says " the Atherine, or sand-smelt, is the variety generally met with" (p. Ioo). In speaking of the sand-eel, he says :- " Any not required for bait should be fried and eaten, as they form a delicious article of food when in roe, but are not so good in winter" (p. 52). In our experience the sand-eel breeds in the winter; but perhaps Mr. Haslope means that after they have spawned they are not so good. $\mathrm{He}$ says of the grey mullet that " they feed chiefly on some kinds of sea-weed and decaying vegetable matter " (p. 95). It is true that algæ are occasionally, and perhaps often, found in the stomachs of grey mullet, but we should put down the staple food of the species as being animal. If we recollect rightly, in the aquarium at the Plymouth laboratory these fish are fed chiefly upon nereid worms. Day says that they are very destructive to molluscs and minute Crustacea, and that they also eat larvæ and ova ("Brit. Fishes," I., p. 234).

The English of the book is not all that can be desired, and badly arranged sentences are far too common. For instance, "In form this fish is very slender and its shape has some resemblance to that of a large sand-eel, which enables it to pursue its prey with great rapidity" (p. 5o). "Great quantities of these crabs are taken in trammels and the shell on the back is so sharp and rough that it quickly cuts the twine, sometimes damaging the nets almost. beyond repair. - They are generally thrown away or used as manure for the gardens" (p. 6o).

The directions as to skinning a ray are exceedingly involved :-

"To skin a Ray, remove a small portion with a sharp knife and grasp it with an old cloth in the left hand. This affords a firm hold, and by its means the whole skin can be readily stripped off. Meanwhile hold the fish firmly with the right hand, making with a knife a hole, or an incision, to enable the fingers to obtain a firm grip. Leave it upon the board in the open air with the flesh side upwards, and when dry it will have attained the consistency of horn, \&c. . . ." (p. 68).

We prefer the old books on the subject of sea fishing, although, as we have said, the practical advice in the present work is thoroughly sound.

Frank Balfour Browne.

\section{MATTER AND FORCE.}

(1) Molecular Forces and Nezetonian Laws. By Alex. Clark. Pp. 237; illustrated. (Glasgow: W. and R. Holmes, 1905 .) Price $3 s$. $6 d$. net.

(2) Explication méchanique de la Matière, de l’Électricité et du Magnétisme. By M. Despaux. Pp. 210. (Paris: Félix Alcan, 1905.)

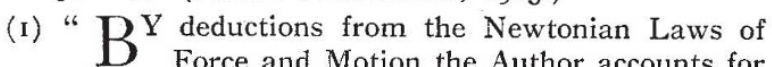
all the facts of Magnetism, Electricity and Chemical Affinity and proves their identity with gravitation" (extract from circular of publisher). We ourselves do not think that the author is successful in his attempt; 